\title{
Chapter 7 \\ Diaspora Policies, Consular Services and Social Protection for Ecuadorian Citizens Abroad
}

\author{
Consuelo Sánchez Bautista
}

\subsection{Introduction}

The analysis of diaspora policies makes it possible to discern, in general terms, national states' relation and commitment to their citizens abroad. Sending states are interested in maintaining their ties to their diaspora populations for different reasons (Weinar 2017; Collier 2013; Lafleur 2011; Gamlen 2006). For example, Ecuador has wanted to respond to its massive emigration, particularly since 1999 when its flow of emigrants increased significantly. However, in the Ecuadorian case it is also relevant to consider the political and social interest that the 1999-2000 so-called 'migration crisis' aroused during and after the 2006 presidential campaign, when the Ecuadorian migration crisis and the Ecuadorian migrants were used as a symbol of both the impact of the economic crisis that had been affecting the country and the opportunity to rebuild the country (Sánchez Bautista 2017). From 2007 till now, the relevance of the migration phenomenon in Ecuador and the state's sustained interest in engaging with Ecuadorians abroad have been made manifest in the recognition of "people in human mobility situations" in the national constitution (2008); in the creation, adaptation, and reform of infrastructure to address human mobility; in the design of various policies and services to serve and protect Ecuadorians abroad, their families in the country, and the returnees; and in the new Organic Law on Human Mobility (Ministerio de Relaciones Exteriores y Movilidad Humana 2017a). Electoral motivations have driven this interest, but also the condition of vulnerability in which the migration of Ecuadorians often happens. Consequently, voting rights for nationals abroad and protection for migrants, particularly those in vulnerable conditions, have been continuously granted after 2007, alongside other

\footnotetext{
C. Sánchez Bautista $(\varangle)$

University of Minnesota, Minneapolis, MN, USA

e-mail: sanch620@umn.edu
} 
services such as providing information about the rights of Ecuadorians abroad, legal assistance, repatriation, and pensions.

Within the diverse bibliography on why and how states relate to their communities abroad, the two-pronged proposal of Gamlen $(2006,2008)$ are particularly relevant for the purpose of this chapter. He explains that states may be interested in building a community abroad through strategies aimed at expanding citizenship for nationals abroad or enlarging cultural policies in destination countries, but, at the same time, they may also be interested in maintaining ties with their diaspora. Weinar (2017) adds to Gamblen's classification by observing that the diaspora engagement policies are related to socio-economic ties and include the creation of institutions and infrastructure to keep those ties alive. Engaging with communities abroad and building and maintaining ties between countries of origin and those communities can be carried out through various policies, programmes, and services that can help to safeguard political, economic, cultural, and social rights, as in the case of Ecuador (Sánchez Bautista 2017), and as this chapter will show, with a specific focus on social protection policies and services implemented by the Ministry of Foreign Affairs and Human Mobility since 2013.

In this sense, the purpose of this chapter is two-fold. The first is to show that Ecuador's policy towards citizens abroad is connected to a political shift in the country and to the new political discourse that appeared as of 2006. The second is to present the central social protection-oriented diaspora engagement policies and services currently in force to protect nationals abroad, specifically those who live overseas permanently and those in vulnerable conditions, although the services are available to all citizens abroad. In particular, I will concentrate on existing social protection policies in the areas of unemployment, health care, pensions, familyrelated benefits, and economic hardship. In doing so, after providing a general overview of the main characteristics of Ecuadorian emigration, I will characterize the general institutional framework whereby Ecuadorian authorities interact with nationals abroad, and I will present a general review of the primary engagement policies for the Ecuadorian diaspora. Then, I will focus on the existing policies, programmes, and services offered by the Ecuadorian state to respond to social protection needs of nationals abroad across the aforementioned specific areas. However, I will not assess how these policies and services have been implemented or whether they respond to nationals abroad needs because such an assessment would go beyond the scope of this chapter. Finally, I will present the main conclusions. 


\subsection{Diaspora Characteristics and Home Country Engagement}

\subsubsection{The Ecuadorian Diaspora and its Relations with the Homeland}

Ecuador has a history of emigration that began back in the 1960s and the 1970s and was mainly to Venezuela, the United States, and Canada (Herrera 2003; Herrera 2007). During the 1970s, emigration continued, but it was in the late 1990s that the first massive wave of Ecuadorian emigration occurred, due to an economic and political crisis in the country (Herrera 2003, 2007, 2011; Herrera et al. 2012).That crisis forced approximately 1.4-1.6 millions of Ecuadorians to leave the country between 1999 and 2005 (Herrera et al. 2012). The most popular destinations during this time were Spain, the United States, Italy, and the United Kingdom. However, between 2004 and 2010, emigration declined due to the implementation of the Schengen Visa and the economic crises that affected Ecuadorians' two main destination countries in particular. During this period, while emigration decreased, return movements increased: the Census of Population and Housing conducted in 2010 reported that, from 2005 to 2010, almost 64,000 people returned to the country (Herrera et al. 2012). These two movements in the recent history of Ecuadorian migration - the massive emigration after 1999 and the return of Ecuadorians during 2004-2010 - have impacted and shaped the political discourse around migration abroad, Ecuadorian migrants, and migration infrastructure and policies.

Before 2000, the Government's actions in relation to migration issues were limited and insufficient and mainly focused on the smuggling of migrants. However, after the first massive wave of migration, when a large Ecuadorian community was living overseas, the Ecuadorian Government started to deploy multiple responses. During the 2000s, it became necessary for the state to recognize and call attention to the massive departure of Ecuadorians and to start creating a new body of policies and a new infrastructure that would respond to that phenomenon (Eguiguren 2011; Sánchez Bautista 2017). The Plan Nacional de Ecuatorianos en el Exterior (2001) (National Plan for Ecuadorians Abroad) was then the first attempt to provide comprehensive services to people about to leave or interested in emigrating, Ecuadorians abroad, and their families in Ecuador (Ministerio de Relaciones Exteriores, Comercio e Integración 2007). Though its full implementation would be problematic (Eguiguren 2011), this national plan was designed with a view to providing attention to emigrants' relatives living in Ecuador; protecting and promoting the rights of Ecuadorians abroad, their official status and documents, and their inclusion in receiving countries; and developing joint programs between origin and destination communities. Additionally, in 2004, one of the Ecuadorian state's priorities was to combat human trafficking and smuggling, yielding as a result the Plan Nacional para combatir la trata de personas, el tráfico ilegal de migrantes, explotación sexual laboral y otros modos de explotación y prostitución de mujeres, niños, niñas y adolescentes, pornografía infantil y corrupción de menores, which took effect in 2006. 
By 2007, the population of Ecuadorians abroad was about 1.6 million people, which accounted for $11 \%$ of the total population of Ecuador and about $30 \%$ of the economically active population (CEPAL 2010). In this context, and since the 2006 presidential campaign, the migration crisis was central to the discourse of the Alianza Pais candidate, Rafael Correa, who took office as president in 2007. The promise of facilitating their return to the homeland and their contribution to economic recovery and development was a cornerstone of the new political project, and Ecuadorians abroad became a symbol of economic recovery and hope (Sánchez Bautista 2017). The motto "we are fixing the house so they can come back" (Secretaría Nacional del Migrante 2007) marked the creation and renewal of strategies to respond to emigrants' needs and the desire of many to be able to return to a country that could offer them better living conditions than before (Margheritis 2016).

This discourse, pivotal during the election campaign and sustained during President Correa's Government, was accompanied by other strategies: giving Ecuadorians abroad the right to vote in presidential and vice presidential elections in Ecuador (granted in 2002, but only enforced as of 2006); extending the migrant vote to elect representatives for Ecuadorian citizens abroad to the Constituent Assembly (in 2007); creating a new and specialized infrastructure, the Secretaría Nacional del Migrante (National Secretariat for Migrants), and redesigning the policies on emigration from a perspective of protection of emigrants and their rights (as of 2007); and enacting a new national constitution that consolidated the previous discourse of Alianza Pais and Correa on migration, which included the recognition of migrants' rights, freedom of movement, and universal citizenship (in 2008). The national constitution recognized people involved in human mobility as a group deserving priority attention.

Considering not only Ecuadorians abroad and returnees but also immigrants, refugees, and people in need of international protection, the concept of "human mobility" became central in the national constitution and in Ecuadorian migration law and policy. ${ }^{2}$ This concept refers to the different types of temporary or permanent migration movements (emigrants, immigrants, refugees, asylum seekers, people in transit, Ecuadorian returnees, victims of human trafficking and smuggling, and their relatives) and is based on the recognition of the right to migrate and migrants' right to voluntary return (Ministerio de Relaciones Exteriores y Movilidad Humana 2017a; Asamblea Constituyente 2008). As of Ecuadorian emigrants, the latest documents such as the Organic Law on Human Mobility and its Regulation (Presidencia de la República de Ecuador 2017) refer to them as Ecuadorians abroad (personas ecuatorianas en el exterior), which would imply that, as Ecuadorian citizens, they

\footnotetext{
${ }^{1}$ In Spanish: "estamos arreglando la casa para que vuelvan.".

${ }^{2}$ Definitions according to Article 3 of the Organic Law on Human Mobility are as follows. Person in a human mobility situation: The person who mobilizes from one state to another with the intention of residing or settling temporarily or permanently therein. Human mobility: Migratory movements performed by a person, family or human group in transit or intending to settle temporarily or permanently in a State other than its homeland or in which it has previously resided, which generates rights and obligations.
} 
keep their rights even beyond the national boundaries no matter their migration status.

Finally, after years of joint work between the Government and civil society, including social organizations of Ecuadorians abroad and returnees, the Organic Law on Human Mobility was launched in 2017-President Correa's last year in office. This Law and its Regulation (2017) stipulate the rights foreseen by the national constitution and represent the materialization of the promise of a "new country' [that] would recognize and strengthen migrants' rights" (Sánchez Bautista 2017, p. 71) made in the 2006 presidential election campaign. In general, they established the political, economic, social, and cultural rights of people in human mobility situations, but particularly those of Ecuadorians abroad and returnees.

\subsubsection{Diaspora Infrastructure}

Since 2000 until now, as mentioned previously, infrastructure and policies have undergone various changes, but I will focus on the most representative milestones after 2013.

The vice ministry of Human Mobility, created in 2013, is the institution currently in charge of the country's migration policy. This office assumed the responsibilities of the former Secretaría Nacional del Migrante (2007-2013) and was incorporated into the administrative structure of the Ministry of Foreign Affairs. Since then, the vice ministry, jointly with a network of 84 embassies, 140 consular offices including honorary consulates and mobile consulates, has been in charge of maintaining communication with the diaspora and responding to the needs of nationals abroad, following constitutional mandates regarding migrants' protection.

According to the document Ministerial Agreement 040 (Ministerio de Relaciones Exteriores y Movilidad Humana May 2017b), the Under-Secretariat of the Ecuadorian Community and, mainly, the Office of Attention and Protection to Ecuadorians Abroad are responsible for planning and coordinating the migration policy to protect Ecuadorians residing abroad. To accomplish this goal, the Office of Attention and Protection to Ecuadorians Abroad has, among others, the responsibility to propose protection policies; to design and implement plans, programs and projects supporting Ecuadorians abroad; to establish protocols for sponsorship, advocacy, and accompaniment in cases of violation of emigrants' rights; to establish guidelines and protocols for the repatriation of corpses and mortal remains of Ecuadorian emigrants; to establish guidelines and protocols for the transfer of detained or incarcerated Ecuadorian citizens and to follow up on these cases; to coordinate and manage international restitution and assistance in cases of separation and subsequent reuniting of children and adolescents; to propose and implement coordination strategies and international cooperation for the care and protection of Ecuadorians abroad; and to define mechanisms to guarantee humanitarian aid to the Ecuadorians abroad and their families, especially in cases of natural disasters and 
emergencies. Generally speaking, these responsibilities reflect the priorities for attention to nationals abroad.

As mentioned before, the vice ministry is responsible for migration policy at a national level but, more recently, the National Plan of Human Mobility (Ministerio de Relaciones Exteriores y Movilidad Humana 2018) has pointed out that the management of migration policy, programmes, and services is a shared responsibility among the state's institutions, according to their responsibilities. Thus, the ministries of Culture, Housing, Education, Health, Justice, Sports, the Interior, and Labor should extend access to some of their programs and services in accordance with the rights of Ecuadorians abroad and returnees, as stated in the Constitution and the Organic Law on Human Mobility and its Regulations.

Moreover, to respond to the needs of nationals abroad and returnees and guarantee their access to rights, the vice ministry coordinates actions with other national institutions, such as the National Secretariat for Higher Education, Science, Technology, and Innovation; the Ecuadorian Social Security Institute; the National Customs Service of Ecuador; the Superintendence of Information and Communication; the Citizens' Council of Citizen Participation and Social Control; and the Office of the Human Rights Ombudsman, the only national institution with offices currently in the United States, Spain, Italy, and Mexico (see Sect. 7.3 for details).

The Executive Order No. 20 (2013) declared that the National Council for Equality and Human Mobility, along with the Vice Ministry of Human Mobility, must address the mainstreaming of migration policy. The participation of the National Council for Equality in the protection of migrants is also reinforced in the National Plan of Human Mobility (Ministerio de Relaciones Exteriores y Movilidad Humana 2018), which states that the National Council for Equality and Human Mobility is the agency in charge of monitoring and assessing the national goals included within the National Development Plan (2017-2021) regarding human mobility. The participation of all these entities to ensure access to rights and services for Ecuadorians abroad is based on the migration policy's management model and principles of co-responsibility, trans-sectoriality, and mainstreaming (Ministerio de Relaciones Exteriores y Movilidad Humana 2018).

The institutional framework for migration is complemented at a local level with regional offices of the vice ministry aimed at providing information and services to migrants and their families. As part of the institutional infrastructure to address the needs of Ecuadorians abroad, the Ministry of Foreign Affairs and Human Mobility also launched the "virtual consulate" (www.consuladovirtual.gob.ec), a webpage designed essentially to request consular procedures online (see next sections for more information). 


\subsubsection{Key Engagement Policies}

The Organic Law on Human Mobility (Ministerio de Relaciones Exteriores y Movilidad Humana 2017), its Regulation (Presidencia de la República de Ecuador 2017) and the National Plan for Human Mobility, launched in May 2018, now offer the main guidelines for Ecuadorian migration policy. ${ }^{3}$ Nevertheless, the national constitution (2008) and other former policies and development plans and documents prepared since 2007 have oriented the policies, programmes, and services offered to nationals abroad until now. Some of the programmes and services offered by the former Secretaría Nacional del Migrante (Sánchez Bautista 2014, 2017) are still in force, while other services have been created to respond to the new challenges faced by Ecuadorians in destination countries.

In general, the country's migration policy must respond to constitutional principles. Since 2008, these fundamental principles recognize, among others, freedom of movement, universal citizenship, and rights for Ecuadorians living abroad, returnees, immigrants and refugees living in the country. In particular, Title II, Chapter Three, Article 40 , states that the country shall provide Ecuadorians abroad with assistance, care, advisory services, and comprehensive protection so that they can exercise their rights; provide safeguards when citizens have been arrested and imprisoned abroad; promote their ties with Ecuador, facilitate family reunification and encourage their voluntary return; and protect transnational families and the rights of their members. The national constitution also states that Ecuadorians residing abroad may be elected to any office and have the right to elect the president, the vice president, and members of the National Assembly (equivalent to the parliament) representing Ecuadorians abroad.

On the other hand, the Organic Law on Human Mobility (2017) establishes as a principle the protection of Ecuadorian citizens abroad and respect for their rights, regardless of their migratory status. These rights are aligned with the national constitution and are the main parameter for the services offered by the Ecuadorian Government to nationals living abroad and returnees as well. ${ }^{4}$ Among their rights, the following are mentioned: citizenship, democratic participation, political organization, and voting rights from abroad; maintaining and transmitting their cultural identity; and access from abroad to plans, programmes, and projects developed in Ecuador: health services and the Ecuadorian Social Security System, education, and justice and legal assistance (see details on this in Table 7.1 and Sect. 7.3).

On another front, the Organic Law on Human Mobility (2017) also provides the principles for consular protection and assistance from diplomatic missions or

\footnotetext{
${ }^{3}$ This law refers to all people in human mobility situations: Ecuadorians abroad, returnees, refugees, asylum seekers, persons in need of international protection, persons in transit, and victims of human trafficking and smuggling. However, herein I am specifically referring to Ecuadorians abroad and, sometimes, returnees.

${ }^{4}$ It is worthwhile to mention that information on services beyond consular procedures for Ecuadorians abroad is not available on the Ministry of Foreign Affairs and Human Mobility's website. However, the Ministry's website offers complete information about services that returnees can access in Ecuador (https://www.cancilleria.gob.ec/catalogo-servicios-migrantes/).
} 
Table 7.1 Policies and main policy strategies concerning Ecuadorians abroad

\begin{tabular}{l|l}
\hline Policies & Policy strategies \\
\hline $\begin{array}{l}\text { To promote universal } \\
\text { citizenship and freedom of } \\
\text { movement in the international } \\
\text { arena }\end{array}$ & $\begin{array}{l}\text { Promoting initiatives to defend Ecuadorian citizens' rights in } \\
\text { international settings }\end{array}$ \\
\hline $\begin{array}{l}\text { To strengthen the protection of } \\
\text { rights of the population in } \\
\text { human mobility situations }\end{array}$ & $\begin{array}{l}\text { Reducing paperwork so that Ecuadorian migrants can access } \\
\text { Ecuadorian public health services; encouraging affiliation to } \\
\text { the healthcare and retirement system of the Ecuadorian Social } \\
\text { Security Institute (IESS) } \\
\text { Implementing an accessible and safe remittance system and } \\
\text { promoting Ecuadorians' active inclusion in the national } \\
\text { financial system from abroad } \\
\text { Implementing effective, efficient, transparent, and quality } \\
\text { consular services } \\
\text { Including Ecuadorians abroad in the commercial, tourist and } \\
\text { cultural promotion of Ecuador } \\
\text { Promoting Ecuadorian cultural values with particular attention } \\
\text { to girls, boys, and adolescents } \\
\text { Strengthening mechanisms for democratic participation abroad }\end{array}$ \\
\hline $\begin{array}{l}\text { To promote safe and orderly } \\
\text { migration }\end{array}$ & $\begin{array}{l}\text { Promoting the rights of victims of human trafficking or } \\
\text { smuggling } \\
\text { Promoting regional mechanisms and bilateral agreements to } \\
\text { prevent risky migration }\end{array}$ \\
\hline $\begin{array}{l}\text { To preserve diversity, } \\
\text { integration, and coexistence of } \\
\text { people in human mobility } \\
\text { situations }\end{array}$ & $\begin{array}{l}\text { Coordinating reciprocity mechanisms with host countries, so } \\
\text { that Ecuadorian migrants can have better guarantees for the } \\
\text { respect of their rights } \\
\text { Supporting associativity and access to resources for the } \\
\text { implementation of cultural and sports projects } \\
\text { Strengthening solidarity and aid networks }\end{array}$ \\
\hline
\end{tabular}

consular offices to complement the aforementioned rights. Consular offices' duties and services are, among others: to coordinate actions with the institutions in charge of economic policies and services to promote investments and family savings; to assess and coordinate assistance in cases of vulnerability; to provide accompaniment in the cases of vulnerable people in hospitals, health centers, or institutions for children, adolescents, and older adults; to accompany Ecuadorians abroad before courts and to provide effective assistance to Ecuadorians deprived of liberty; to coordinate the care and protection of victims of human trafficking or smuggling; and to promote access to, and the production and circulation of, arts, and cultural heritage.

As for mobile consulates, their goal is to extend consular services to places with a significant number of Ecuadorians who have no access to permanent consular offices. Mobile consulates offer the same kinds of services provided by consular offices, such as issuing passports; renewing national ID renewals or issuing consular ID cards in countries where this document is available; issuing police records, powers of attorney, notarial records, and affidavits; registering place of residence for 
census and election purposes according to the law ${ }^{5}$; and providing attention to cases of vulnerability (see details on this below), as well as legal advice and information about rights and services available to Ecuadorians abroad. These services vary as a function of consular resources and special needs based on local contexts in receiving countries.

On the other hand, based on premises of the Constitution and the Organic Law on Human Mobility as well as the policy guidelines provided by the National Development Plan (2017-2021), the National Plan for Human Mobility (2018) is built upon four fundamental policies focusing on persons in human mobility situations. These core policies are as follows: (a) to promote universal citizenship and freedom of movement in the international arena; (b) to strengthen the protection of rights of the population in human mobility situations; (c) to promote safe and orderly migration; and (d) to preserve diversity, integration, and coexistence of people in human mobility situations.

Along with the four overarching policies and the policy strategies (see Table 7.1), the National Plan for Human Mobility (2018) considers a level of policy action which provides advice on the kind of measures that should be considered in implementing the policies. Some of these actions are already being developed, but others need to be planned and designed throughout the implementation of the National Plan.

Beyond these rights and policies, and the services offered by the consular offices as described above, the Ecuadorian Government has been supporting Ecuadorians abroad through a wide variety of services offered in Ecuador by national governmental institutions such as ministries. In the past, the Secretaría Nacional del Migrante itself offered services to Ecuadorians abroad and their families. However, the new institutional framework in effect since the creation of the Vice Ministry of Human Mobility in 2013 has instead encouraged the inclusion and access of Ecuadorians abroad to services offered to all other Ecuadorian citizens, including returnees living in Ecuador as well.

In this context, it is worth mentioning some of the services available in Ecuador to Ecuadorians abroad, their families, and returnees. These include access to mortgage loans and economic incentives granted by the national Government through the Ministry of Urban Development and Housing. Ecuadorian citizens living in Ecuador and abroad, immigrants, returnees, and refugees can apply to the allowance for construction of their own housing on their own land (bono para construcción de vivienda), the allowance for housing improvement (bono para mejora de vivienda) and the Manuela Espejo grant to persons with disabilities who are registered as such in the Ministry of Public Health of Ecuador, on the basis of the law and their critical

\footnotetext{
${ }^{5}$ Although voting is mandatory in Ecuador, it is optional for Ecuadorians living abroad. To exercise this right, Ecuadorians must be registered in the consular office nearest their home. Once a citizen abroad is registered in a office, he or she can also access services online or in person, such as the " $4 \times 4$ system" among others. Ecuadorians abroad who are in the consular register at the same time keep all their data in the Civil Registry and other institutions and can access services inside Ecuador, as described in Sect. II.
} 
or vulnerable socio-economic condition, in order to provide them with adequate housing for their needs and or to improve living conditions and accessibility.

Regarding economic programs offered to all Ecuadorians living abroad, their families, and returnees, the " $4 \times 4$ system" service aims to facilitate transfer of goods from Ecuadorians abroad to their families in Ecuador through a tax exemption system. Similarly, to facilitate the return of Ecuadorian migrants, the Ecuadorian Customs Service offers a "Tax-Exempt Household Goods" service (updated in 2018), aimed particularly at Ecuadorians who have lived abroad for at least 2 years and want to take household goods back to Ecuador.

The consular offices also provide services and encourage the social participation of Ecuadorians living abroad through activities tailored to migrants' needs and interests in their destination countries. In Spain, for instance, the Centro Cultural Ecuatoriano in Madrid, created by the Ministry of Foreign Affairs and Human Mobility and launched in December 2017, seeks to promote the cultural heritage of the country by developing activities related to Ecuadorian art, cinema and literature, as well as workshops to promote civic engagement.

Although there is not a particular policy regarding non-formal education courses or workshops, training can be offered by consular offices but will depend on local needs and the consular offices' resources. These courses are geared to providing skills for economic integration. For example, the Escuela del Migrante program in Spain offers free education and training for unemployed Ecuadorians and workshops to develop job search skills. Sales, computer literacy, entrepreneurship, tourism, and networking courses are also available for Ecuadorians living in Spain, Italy, and other countries.

Regarding formal education, Ecuadorians living abroad can take the exam Ser Bachiller, a standardized national exam required to access higher education in public institutions in Ecuador. In 2018, Ecuadorians abroad living in Chile, Colombia, Costa Rica, Cuba, El Salvador, Germany, Guatemala, Honduras, Italy, Panama, Peru, Spain, the United States, and Venezuela took the exam (Secretaría de Educación Superior, Ciencia, Tecnología e Innovación 2018). Likewise, since 2018 the Ministry of Education has offered an online literacy, primary, and secondary education program for Ecuadorians who are residing in Italy, Spain, and the United States who are at least 3 years behind in their education or who are over 18 years old and have had no opportunity to complete high school. Once the courses are completed, Ecuadorians abroad can obtain a high-school degree, which will allow them to access higher education and technical certifications. For the Vice Ministry of Human Mobility, this service makes effective the portability of rights for Ecuadorians abroad, in accordance with the principle of universal citizenship (Ministerio de Educación 2017). 


\subsection{Diaspora Policies and Social Protection in Ecuador}

As already described, the rights of Ecuadorians abroad are enforced in the national constitution and the Organic Law on Human Mobility and its Regulation. This law is complemented by the policy guidelines provided by the National Plan for Human Mobility to meet the needs of Ecuadorians abroad and to ensure their access to rights. As for social protection-oriented norms, policies, and services, these are addressed to all Ecuadorians abroad but give special attention to those in vulnerable situations, whether because of economic or social restraints, health issues, documentation issues, gender, or age. In the effort to provide attention to the population in a human mobility situation, the Ministry of Foreign Affairs and Human Mobility coordinates actions with consular offices and other national institutions to implement the migration policy and the trans-sectoral strategy. Although Ecuadorians abroad do not receive any cash assistance benefit from the Ecuadorian Government, ${ }^{6}$ there is a variety of other services from which they can benefit, such as information services, legal advice offered by consular offices for specific challenges faced by Ecuadorian migrants in host countries, and repatriation.

Ecuadorians abroad can learn about their rights and the services provided by consular offices in host countries and national institutions in Ecuador through different resources. The Ministry of International Affairs and Human Mobility's website provides general information on policies and rights, as well as documents related to the human mobility law and regulations. Additionally, the Ministry has launched the online application "Ecuador Contigo," which allows migrants abroad to access information regarding services offered by consular offices, a list of 24-hour contact telephone numbers to reach out in emergencies, information about the rights of Ecuadorians in host countries, and information on how to process the returning migrant certificate (certificado de persona ecuatoriana retornada). As part of the contingency plan implemented to deal with migration challenges posed by securitization measures adopted by the United States, this app also provides videos and digital bulletins about migrant's rights, legal advice, and general advice in case of detention. Through this app, Ecuadorians abroad can also access information about the virtual consulate, a tool included on the webpage of the Ministry of Foreign Affairs and Human Mobility that allows its users to apply for, request, and manage the different services offered by the consular offices, e.g., legalizations and notary records, certifications, travel documents, powers of attorney, last wills and testaments, and registration and certification of births, deaths, marriages and divorces. All the products and services provided through the virtual consulate may be either fully online, which means that they do not require the presence of the person at all, or partially online, which means that someone's presence will be required at some point after filing an application.

\footnotetext{
${ }^{6}$ Within the normative framework there is no explicit information about direct cash assistance for Ecuadorians abroad, although some home country benefits in involve allowances such as housing subsidies and access to loans.
} 
Each ministry or national institution in Ecuador often provides information on special programs or benefits for Ecuadorians living abroad and returnees. For instance, the Ecuadorian Social Security Institute's webpage provides concise information about voluntary affiliation to the Ecuadorian Social Security Institute (IESS) for Ecuadorians living abroad, retirement pensions, health insurance, maternity leave and stipends, healthcare subsidies, disability benefits, stipends for the elderly, and death-related benefits. In addition, the consular offices' social media accounts usually share news and updated information regarding services offered in Ecuador and local services and activities in host countries.

As for legal advice, consular offices provide this service free of charge as part of their responsibilities. It is worth mentioning that Article 214 of the Constitution states that the Office of the Human Rights Ombudsman shall have delegations abroad to protect and safeguard the rights of Ecuadorians and provide assistance in cases of vulnerability. ${ }^{7}$ In general, the protection responsibilities of the Ombudsman are carried out within the framework of advice, informal negotiations, legal actions, strategic litigation, visits to detained persons in the host country in coordination with the Ecuadorian consular offices, assistance in cases of deportation, legal advice in cases of evictions and mortgages, and dialogue with human rights institutions in host countries, as well as with groups of Ecuadorians abroad to listen and attend to their particular needs, in keeping with the Ombudsman's competences.

Legal advice provided by consular offices depends on resources, local immigration contexts, and migrants' needs in particular settings as well. For example, in Spain, consular offices deliver legal advice in events of unfair dismissals, evictions, and mortgages (since 2012), and financial loans. They also offer legal support during the process of negotiations with financial institutions, family reunification efforts, alimony, detentions and/or expulsions. Likewise, Ecuadorians living in Spain can receive legal support in matters related to access to host country social protection services. ${ }^{8}$ In Italy, protection services to Ecuadorian migrants include legal sponsorship and psychosocial support in cases of children and adolescents removed from their families, and talks and information about gender and family violence and the care and custody of children.

Concerning repatriation services, these are offered on a case-by-case basis as a function of vulnerability. As part of the key protection measures stipulated in the normative and policy documents, the Organic Law on Human Mobility grants priority attention to Ecuadorians abroad in vulnerable situations. The status of vulnerability is declared by the Vice Ministry of Human Mobility in Ecuador or through diplomatic missions or consular offices abroad. Exceptional cases for repatriation of people in vulnerable conditions are considered, as will be discussed latter.

\footnotetext{
${ }^{7}$ The Office of the Human Rights Ombudsman opened one of its first delegations in Madrid in 2001.

${ }^{8}$ Affiliation to the Spanish social security regime is possible under the "Security Agreement between Ecuador and Spain" (2009). This agreement ensures the portability of rights for both Ecuadorians and Spanish living in both countries.
} 
There are a few other social protection services that cover Ecuadorians abroad. The following paragraphs will discuss policies and services regarding unemployment, health care, pensions, family-related benefits, and economic hardship.

\subsubsection{Unemployment}

Although there is a policy regarding national unemployment insurance that covers Ecuadorians living in the country, the Ecuadorian Government does not offer unemployment benefits for migrants abroad. For Ecuadorians living in Ecuador, the unemployment insurance application should be made from day 61 of being unemployed and up to 45 days after this date. An additional requirement is to have 24 non-simultaneous contributions to the national social security system through a position requiring an employment contract (Ecuadorians abroad only can be affiliated on a voluntary basis); to have six continuous contributions immediately before unemployment; not to be retired; and not to have voluntarily resigned.

However, Ecuadorians abroad can apply for a severance payment (individual unemployment reserve fund) if they have been voluntarily affiliated to the Ecuadorian Social Security Institute (IESS) (voluntary affiliation to the Ecuadorian Social Security Institute is eagerly encouraged by the national Government). In this case, Ecuadorians abroad can request the reimbursement of this contribution (3\% of their salary income until February 2006, and 2\% after this date). The severance pay amount is determined on the basis of the amount of the contributions, which are established according to individual salaries. The request must be made through the web portal www.iessgob.ec. Ecuadorians abroad do not need to comply with the requirement of number of contributions (24 for persons living in Ecuador), the waiting time (60 days without paying voluntary or mandatory affiliation to the IESS) or the unemployed status. The individual unemployment fund can also be requested for maternity or paternity leave (if parents do not receive a salary during this period). Ecuadorians abroad can therefore access this benefit if they are voluntarily affiliated to the IESS.

On another front, as mentioned before, education and training for economic integration and development of labor skills are offered by some consular offices in host countries. This is not a policy, but consular offices offer this kind of service according to the needs of Ecuadorians abroad.

\subsubsection{Health Care}

Health coverage and assistance for emigrants is provided in Ecuador by the national health system. Nationals abroad can maintain health coverage only if they pay for voluntary affiliation to the IESS, and they will have the same healthcare options designed for citizens in Ecuador. Ecuadorians abroad who are voluntarily affiliated 
to the IESS can only access health services and benefits in Ecuador, but can do so even if they are only in the country temporarily. Healthcare benefits include occupational risks, sickness and maternity assistance in Ecuador, and health coverage for migrants' children under 18 years old living in Ecuador.

Healthcare benefits for people with disabilities have been a mainstream policy in Ecuador since 2007. Specifically, the Ministry for Economic and Social Inclusion (MIES) provides free assistance to people with disabilities in conditions of poverty or extreme poverty at the national level through direct administrative centers and cooperating entities. Nevertheless, Ecuadorians abroad cannot access this type of service unless they return to the country and apply for the services delivered by the MIES. One exception is made in the case that Ecuadorians abroad wish to apply for the disability certification as a requirement to access healthcare and economic benefits in Ecuador. Ecuadorians abroad can apply to a provisional certificate of disability by presenting the requirements in the Ecuadorian consular office in the country of residence. In Ecuador, the Ministry of Public Health is in charge of assessing the type and the severity of the disability and issuing the certificates. If Ecuadorians abroad meet the requirements, they will receive the provisional certificate electronically. Once they return to Ecuador, within 90 days after receiving the certificate, they must undergo physical verification (qualification or requalification). Ecuadorians with disabilities living abroad who have been qualified and who manifest their express wish to return to the country can enjoy state benefits, as well as the benefits enshrined in the law and in its regulations, according to their degree of disability, as soon as they enter the country.

At a regional level, access to health services works differently within the member states of the Andean Community (CAN) (Bolivia, Colombia, Ecuador and Peru). The Andean Social Security Instrument establishes that health services required by migrant workers in host countries, when they are affiliated to the social security system in their country of origin, will be provided by the host country and reimbursed by their country of origin.

Consulates do not seem to play an active role in the effort of Ecuadorians abroad to access health services in Ecuador. Any inquiries on voluntary affiliations to the IESS and other benefits should be addressed to the IESS in Ecuador through its website, via Skype or by phone.

\subsubsection{Pensions}

Ecuador has signed bilateral social security agreements (BSSA) with pensionrelated provisions with the following countries: CAN member states (Bolivia, Colombia, and Peru), Chile, Netherlands, Paraguay, Spain, Uruguay, and Venezuela. According to the IEES in charge of this policy, bilateral agreements do not include health care of medical assistance for Ecuadorian emigrants in Ecuador. However, in the case of the Andean Community members, Bolivia, Colombia, and Peru will offer to citizens from the other CAN members states the same treatment as nationals 
regarding social security benefits, according to local laws. This disposition only applies to labor migrants and their beneficiaries affiliated to the national social security scheme.

In the case of Ecuadorians living in Spain, the International cooperation social security agreement between Spain and Ecuador provides Ecuadorians with economic benefits for permanent disability, retirement and survival, and economic benefits for work accidents and occupational diseases. On the other hand, the international cooperation social security agreement between Chile and Ecuador provides Ecuadorians with economic benefits for permanent disability, retirement, and survival. For any other countries without bilateral agreements with Ecuador in this matter Ecuadorians abroad voluntary affiliated to the Ecuadorian Social Security Institute can apply to obtain pension benefits in Ecuador if they meet the requirements.

The IESS requires that Ecuadorians must apply for pensions at the residence country only if there exists an international cooperation agreement between Ecuador and the country of residence. When submitting the documentation, through the IESS portal, the application for both countries will be generated and, if the requirements are met, two pensions could be approved, and they will be calculated proportionally, according to the contributions made in each country.

Consular offices can issue documents and certificates needed to apply to cash pension rights, such as special powers and life certificates. In case that the life certificate is required for the retirement pension, beneficiaries should visit the consular office and provide originals and copies of their passport and ID and two photographs. To apply to survivors benefits for dependents the person concerned should be present at the consular office and bring originals and copies of the passport and the ID; affiliation data with updated marital status for all cases; and marriage, divorce, or death certificates when applicable. These certifications are free and have 1 -year validity.

\subsubsection{Family-Related Benefits}

The services offered by the Ecuadorian state to Ecuadorians abroad include very few cash benefits for families besides the individual unemployment fund (see above), which can also be requested for maternity or paternity leave, if parents do not receive a salary during this period. Family-related benefits are oriented to other kinds of services, such as identity documentation and psychological and legal advice.

Consular offices can issue birth certificates and deliver other services such as timely and late birth registration. In the Ecuadorian consulates, children born abroad, of any age, may be registered as a son/daughter of an Ecuadorian father and/ or mother.

Additionally, in the fulfilment of its duties, the Ministry of International Affairs and Human Mobility, through its consular offices and the delegates of the Office of the Human Rights Ombudsman, where applicable, provides legal advice on issues 
related to cases of children and adolescents removed from their families (as in the case of Ecuadorian families in Italy), gender violence, family violence, care and custody of children, locating of persons (detainees and missing), repatriation of people in vulnerable situations, repatriation of the deceased and mortal remains; psychosocial care for migrants' family members, high-risk migration prevention, and general information about consular services and ways to access protection services in Ecuador for people in a vulnerable situation.

\subsubsection{Guaranteed Minimum Resources}

The Ecuadorian Government's mechanism to protect Ecuadorians abroad from extreme hardship is repatriation of persons in vulnerable condition and exceptional cases, since there are no other guaranteed minimum cash benefits available for Ecuadorians abroad in situations of vulnerability.

Article 21 of the Organic Law of Human Mobility states that Ecuadorians abroad in situation of vulnerability, whether in transit or living in the country of destination, will receive priority attention. Complementarily, Article 39 refers to exceptional cases $^{9}$ of repatriation of Ecuadorians in situations of vulnerability. Repatriation is defined as the assisted return to Ecuador under the partial or total custody of the state, in cases of people deprived of freedom, children or adolescents who are not accompanied or are in vulnerable situations, victims of human trafficking or smuggling of migrants, people with catastrophic or terminal diseases, and other cases determined as exceptional by the competent human mobility officials.

The status of vulnerability must be declared by the Vice Ministry of Human Mobility in Ecuador or through diplomatic missions or consular offices abroad. In general, vulnerability will be recognized in the following situations: limited economic resources and irregular status; children or adolescents not accompanied by, or separated from their parents; senior citizens, pregnant women, persons with disabilities or catastrophic or highly complex diseases; victims of family or gender violence or discrimination and xenophobia; detainees; homelessness; victims of human trafficking or smuggling; and persons affected by migration or social policies in their destination countries.

People in vulnerable situations should request the recognition of this situation from the Vice Ministry of Human Mobility or to the consular or diplomatic offices abroad. However, the procedures to request this declaration of vulnerability are not clear in the Regulations of the Organic Law on Human Mobility. ${ }^{10}$

\footnotetext{
${ }^{9}$ The Regulations of the Organic Law regard as exceptional those cases described under the definition of situations of vulnerability. However, the Organic Law on Human Mobility defines in different articles the situations in which Ecuadorians abroad are considered vulnerable (Article 21) and cases that are considered exceptional (Article 39). These are already included in Article 21.

${ }^{10}$ The Regulations only detail the requirements for applying for repatriation of corpse or the mortal remains (Sect. III, Articles 10 to 14).
} 
Repatriation requests are reviewed and approved by the Vice Ministry of Human Mobility or consular or diplomatic offices abroad in cases of vulnerability or in exceptional cases as described above. To approve the applications, the officials will assess the risks for individual and family safety and security. Article 3 of the Regulations of the Organic Law on Human Mobility establishes that the person identified as vulnerable by the competent authority will be protected and will receive priority attention in keeping with the mechanisms that can be implemented by the authorities. Family members do not have to reimburse the cost associated with repatriation. Additionally, transportation, accommodation or foster care can be provided in Ecuador and in the country of destination with no reimbursement obligations.

Finally, the national Government in coordination with the consular offices provides repatriation of the deceased for families in vulnerable situations. However, the Ministry of Foreign Affairs and Human Mobility does not cover the costs of funeral services or burial sites, but rather only repatriation expenses for the corpse or the mortal remains (ashes) to Ecuador; these costs do not have to be reimbursed. The service will be granted only when the deceased person and his/her family have a vulnerable socio-economic situation, which must be corroborated before the expense is approved. For this evaluation, the applicants both in the country in which the person died and in Ecuador must meet certain requirements. There will be two applicants: one abroad, who will contact the consulate closest to the place of death; the second in Ecuador, who will contact the Vice Ministry of Human Mobility. The required documents are the application for repatriation services, which must be submitted to the Ministry of Foreign Affairs and Human Mobility of Ecuador; a copy of the ID of the family member requesting the repatriation; and a copy of the ID, passport or birth certificate of the deceased.

\subsection{Conclusions}

Since 2000, when the emigration of Ecuadorians became a visible reality, the Ecuadorian state has been designing and implementing different strategies to protect its citizens abroad. However, starting in 2007, the process of strengthening and revamping Ecuadorian migration policies became rooted in a strategic electoral discourse by the Alianza País presidential candidate, who aimed at leveraging the votes of Ecuadorians overseas. Thus, since that moment and after President Correa took office, Ecuador has had the time to build a set of laws, regulations, and policies and an administrative infrastructure to cope particularly with the needs of its nationals abroad and returnees, and to establish strategic relations with Ecuadorians abroad. Beyond political will, it is also worth considering that the changes implemented regarding the infrastructure, programmes, and services offered have been shaped according to the availability of state resources as well. Thus, after Ecuador started its economic recovery following the hike in oil prices during President Correa's mandate, it was more feasible for the Government to strengthen the migration policy despite the fluctuations in their implementation. 
In terms of the relation between the Ecuadorian state and its diaspora, it is worth mentioning that, despite the fact that campaign rhetoric had referred to Ecuadorian emigrants as "compatriots" and "brothers and sisters", within the current norms, they are called "Ecuadorians abroad". This term is meant to highlight the fact that they belong to the territory, are entitled to their rights as Ecuadorian citizens, and are protected by the state beyond its geographical borders-rather than to call attention to their migratory status or their circumstances as emigrants overseas. They are also referred to as "people in human mobility situations", which implies the recognition of their rights, including the right to migrate.

From 2007 to date, a variety of reforms have been made to the administrative infrastructure, norms, policies, and programmes, but the spirit of protection for Ecuadorian migrants and their families has remained. At the time of writing this chapter (January 2019), in terms of norms and policies, the Constitution (2008), the Organic Law on Human Mobility (2017) and its Regulation (2017), and the National Plan for Human Mobility (2018) are the main guidelines for the Ecuadorian institutions' efforts to guarantee the rights of Ecuadorian migrants and, accordingly, to provide services in Ecuador and abroad. To this end, in terms of infrastructure, the Ministry of Foreign Affairs and Human Mobility, with its network of consular offices, and in coordination with the different ministries and other governmental agencies in Ecuador-in keeping with the trans-sectoral strategy to guarantee the rights of Ecuadorian migrants - is actually in charge of implementing the legal provisions and the diaspora engagement policies in force in Ecuador. These protectionoriented norms, policies, and services are aimed at all Ecuadorian migrants, but give particular attention to those in vulnerable situations, whether because of economic or social constraints, health issues, documentation matters, gender, or age.

Specific rights of Ecuadorian migrants are recognized in the documents mentioned previously, and services should therefore be provided to allow Ecuadorian citizens to exercise their rights from abroad. Despite the fact that the Ecuadorian Government does not offer any kind of direct cash support to emigrants in their countries of destination, the consular offices are in charge of providing protection, assistance, and services such as paperwork and documentation, information about rights in Ecuador and in countries of destination, legal advice and accompaniment and monitoring in cases of legal actions, assistance in cases of vulnerability, repatriation, workshops, and informal programs that promote Ecuadorian culture.

Additionally, the Government has been supporting Ecuadorians abroad through a wide variety of services now offered by national governmental institutions such as the ministries or secretariats. The Ecuadorian migrants abroad and returnees can access mostly the same kinds of programs and services as any Ecuadorian living in the country. However, some of the benefits can only be enjoyed in Ecuador, such as health services, housing credits, or access to the public higher education system, which is free in Ecuador.

Although the social protection policies for Ecuadorians abroad exist and are particularly focused on cases of vulnerability, they do not include any unemployment or cash benefits for Ecuadorians living in other countries. When economic, healthrelated, or any other kind of vulnerability exists, the answer is repatriation, and it is 
granted on a case-by-case basis. However, in general terms, the programmes and services offered by the Vice Ministry of Human Mobility and the consular offices are in accordance with the rights of Ecuadorians abroad and their families as stipulated in the Constitution, the Organic Law on Human Mobility, and its Regulations.

After 2 years of having a new Government in the country, some of the services provided continue to be implemented, and the infrastructure seems to have become consolidated. This is evident in the National Plan of Human Mobility (2018), even though the functions of the National Council for Equality and Human Mobility would still need to be strengthened. This body is relevant since its role is to monitor and assess public policy regarding human mobility. Also, it is important to acknowledge that the implementation of the policies regarding Ecuadorian migrants and the services provided to this population might suffer modifications due to the country's current economic situation and the Government's priorities. In any case, the results seen in coming years will make it possible to determine whether Ecuador has finally consolidated a migration policy made by the state to supersede a policy made by a specific administration, i.e., a policy that can outlast political interests and governmental changes.

Acknowledgements This chapter is part of the project "Migration and Transnational Social Protection in (Post)Crisis Europe (MiTSoPro)" that has received funding from the European Research Council (ERC) under the European Union's Horizon 2020 research and innovation programme (Grant agreement No. 680014). In addition to this chapter, readers can find a series of indicators comparing national social protection and diaspora policies across 40 countries on the following website: http://labos.ulg.ac.be/socialprotection/

\section{References}

Asamblea Constituyente. (2008). Constitución política de Ecuador. Ecuador: Gobierno del Ecuador.

CEPAL. (Septiembre de2010). Resumen del estudio sobre marcos institucionales normativos y de políticas sobre migración internacional en la Argentina, Chile y el Ecuador. Santiago de Chile.

Collier, M. (2013). Emigration nations. Policies and ideologies of emigrant engagement [online]. London/New York: Palgrave Macmillan.

Eguiguren, M. (2011). Sujeto migrante, crisis y tutela estatal. Quito: Flacso Ecuador.

Gamlen, A. (2006). Diaspora engagement policies: What are they, and what kind of states use them? (Centre on Migration, Policy and Society. Working Paper 32). Oxford University of Oxford.

Gamlen, A. (2008). The emigration state and the modern geopolitical imagination. Political Geography, 27(8), 840-856.

Herrera, G. (2003). La migración vista desde el lugar de origen. Iconos, 15, 86-94.

Herrera, G. (2007). Ecuatorianos/as en Europa: de la vertiginosa salida a la construcción de espacios trasnacionales. In I. Yepes \& G. Herrera (Eds.), Las migraciones Europa América Latina (pp. 189-216). Quito: FLACSO-OBREAL-UCL-Universidad de Barcelona.

Herrera, G. (2011). La familia migrante en las políticas públicas del Ecuador: de símbolo de la tragedia a objeto de intervención. In B. Feldman-Bianco, L. Rivera, C. Stefoni, \& M. Villa (Eds.), La construcción social del sujeto migrante en America Latina. Prácticas, representaciones y categorías. Quito: FLACSO Ecuador, CLACSO, Universidad Alberto Hurtado. 
Herrera, G., Moncayo, M. I., \& Escobar, A. (2012). Perfil migratorio del Ecuador 2011. Quito: IOM. Lafleur, J. M. (2011). Why do states enfranchise citizens abroad? Comparative insights from Mexico, Italy and Belgium. Global Networks, 11, 481-501.

Margheritis, A. (2016). Migration governance across regions. State-diaspora relations in the Latin American-Southern Europe corridor. New York: Routledge.

Ministerio de Educación (2017). MinEduc y Cancillería presentan bachillerato a distancia para compatriotas que viven en Estados Unidos.. Retrieved from Ministerio de Educación: https:// educacion.gob.ec/mineduc-y-cancilleria-presentan-bachillerato-a-distancia-para-compatriotas-que-viven-en-estados-unidos/

Ministerio de Relaciones Exteriores, Comercio e Integración. (July 2007). Política migratoria del Ecuador. Quito, Ecuador: https://www.refworld.org/pdfid/49002e312.pdf.

Ministerio de Relaciones Exteriores y Movilidad Humana. (2017a). Ley Orgánica de Movilidad Humana. Registro Oficial 938. Ecuador: Gobierno del Ecuador.

Ministerio de Relaciones Exteriores y Movilidad Humana. (2017b, May). Estatuto orgánico de gestión organizacional por procesos del Ministerio de Relaciones Exteriores y Movilidad Humana. Ecuador: Gobierno del Ecuador.

Ministerio de Relaciones Exteriores y Movilidad Humana. (2018). Plan Nacional de Movilidad Humana. Ecuador: Gobierno del Ecuador.

Presidencia de la República de Ecuador. (2017). Reglamento de la Ley Orgánica de Movilidad Humana. Decreto 111. Ecuador: Gobierno del Ecuador.

Sánchez Bautista, C. (2014). Policy and institutional frameworks: Country report Ecuador. INTERACT RR 2014/24, Robert Schuman Centre for Advanced Studies. San Domenico di Fiesole (FI): European University Institute.

Sánchez Bautista, C. (2017). The promise of a welfare state: The Ecuadorian government strategy on emigration and diaspora policies between 2007-2016. In A. Weinar (Ed.), Emigration and diaspora policies in the age of mobility. London: Springer.

Secretaría de Educación Superior, Ciencia, Tecnología e Innovación. (2018, February 19). Inicia toma del examen Ser Bachiller. Retrieved from Secretaría de Educación Superior, Ciencia, Tecnología e Innovación: https://www.educacionsuperior.gob.ec/ inicia-toma-del-examen-ser-bachiller-primer-semestre-2018/

Secretaría Nacional del Migrante. (2007). Plan nacional de desarrollo humano para las migraciones 2007-2010. Ecuador: Gobierno del Ecuador.

Weinar, A. (Ed.). (2017). Emigration and diaspora policies in the age of mobility. London: Springer.

Open Access This chapter is licensed under the terms of the Creative Commons Attribution 4.0 International License (http://creativecommons.org/licenses/by/4.0/), which permits use, sharing, adaptation, distribution and reproduction in any medium or format, as long as you give appropriate credit to the original author(s) and the source, provide a link to the Creative Commons license and indicate if changes were made.

The images or other third party material in this chapter are included in the chapter's Creative Commons license, unless indicated otherwise in a credit line to the material. If material is not included in the chapter's Creative Commons license and your intended use is not permitted by statutory regulation or exceeds the permitted use, you will need to obtain permission directly from the copyright holder. 